\title{
Increasing Insulin Prices - Role of Pharmacists in Assisting Patients with Diabetes to Enhance Access
}

\author{
Hyma P Gogineni ${ }^{1 *}$ and Revant V Gogineni ${ }^{2}$ \\ ${ }^{1}$ Department of Pharmacy Practice and Administration, University of Health Sciences, USA \\ ${ }^{2}$ BS Candidate major in Physiology \& Neurology 2018, USCD, USA
}

Received: 阱 August 14, 2018; Published: 制 August 23, 2018

*Corresponding author: Hyma P Gogineni, Pharm D, Assistant Professor, BPS Ambulatory Care Speciality Council Department of Pharmacy Practice and Administration, Western University of Health Sciences, College of Pharmacy, Pomona, USA

\begin{abstract}
Insulin access has been challenging for many patients as the insulin price has been nearly tripled between 2002 to 2013. The ADA released a white paper on insulin access and affordability and the authors concluded that there is a lack of transparency in the insulin supply chain and patients with diabetes are financially harmed with increasing insulin prices and prescribing patterns favored more expensive insulin analogs. The ADA recommended healthcare providers including pharmacists should educate patients about the cost of insulin, pros, cons and its financial implications. Pharmacists are uniquely situated in community, ambulatory care and institutional settings to guide patients and other healthcare providers on various resources available for patients with diabetes to obtain insulin at no cost to reduced cost based on patient's health plan, income level and Medicare Part D coverage gap and uninsured patients.

Majority of these resources are web-based and available for both patients and other healthcare providers by a click of a button. Educating patients with diabetes about various options to obtain insulin with the lowest price possible is only a short-term solution. Pharmacists need to be part of the long-term solution as it relies on multiple approaches including call for increase transparency in the insulin supply chain, conducting clinical research comparing human insulin vs insulin analogs and being part of the legislative changes.
\end{abstract}

Keywords: Insulin; Cost; Pharmacists; Patient Assistance Programs; Prescription Savings; Copay Cards

\section{Introduction}

Insulin discovery is a major breakthrough in medicine and in patients with diabetes. Fredrick Banting, John Macleod, Charles Best, and JB Collip extracted pancreatic islet extract, which they named "islet in" initially and then renamed this as insulin [1-2]. The first injection of the insulin was given to a 14-year-old boy with promising results. Rosenfeld L [1] In 1923, Banting, Best, and Macleod were awarded the Noble Prize for their work. The team knew that this treatment was extremely needed and wanted to make sure the public could have access to this, so they made a move for the common good; saying that the profit was not their goal and sold the patent to the University of Toronto for a total of three dollars. The University of Toronto held the patent in 1923 and licensed it to companies worldwide preventing a single company developing a profitable monopoly for an essential life-saving drug for Type 1 diabetes [2].

Since the discovery of insulin in 1922 many lives of patients with diabetes have been saved and currently there are about 7.5 million Americans with diabetes using one or more formulations of insulin [3-4]. Diabetes is the primary cause of death in the United States and it costs more than $\$ 327$ billion per year [5]. These raising costs are associated with increasing prevalence of diabetes and expenditure associated with each individual. If patients with diabetes are unable to get insulin or using lower doses of insulin or skipping insulin as they can't afford the insulin can have serious consequences for their health. Access to insulin and appropriate use of insulin is key in achieving optimal blood glucose control and reducing overall mortality and morbidity in patients with diabetes [2-4]. Increasing cost of insulin has serious negative health consequences in patients with diabetes [5-8].

\section{Discussion}

Recently American Diabetes Association (ADA) published a white paper on insulin access and affordability. The authors' conclusions and recommendations are as follows [9].

\section{Conclusion}

a) The average list price of insulin has been tripled between 2002 and 2013, putting patients at high risk for medication non-adherence.

b) Complexity and lack of insulin pricing guidelines favors mediators such as wholesalers, pharmacy benefit manager (PBM), and pharmacies over patients.

c) High out-of-pocket costs has a negative consequence in patients with diabetes. 
d) Cost of development and approval of biosimilar insulin analogs can be expensive.

e) Prescribers and patients favor newer, more expensive insulin analogs over older insulins including human insulins.

\section{Recommendations}

a) Providers, pharmacists, and health plans should initiate the discussion with patients with diabetes about the cost of various insulin formulations, pros and cons, and its impact on their health.

b) Providers should be prescribing the lowest-priced insulin based on patient specific characteristics.

c) Potential research opportunities for the comparative therapeutic and cost effectiveness of various insulins.

d) Needs more transparency throughout the insulin supply chain.

e) Encourage innovation in the development of newer effective insulin preparations.

f) PBMs and payers should use rebates to lower costs for insulin at the point of sale.

Table 1: *Not all assistance programs are available to Medicare patients, be sure to check patients' eligibility ${ }^{\wedge}$ Providers must order the needles for the Flexpen, FlexTouch and Vicotoza otherwise patients will not receive the needles.

\begin{tabular}{|c|c|c|c|}
\hline \multicolumn{4}{|c|}{ Pharmaceutical Company Patient Assistance Programs and Copay Cards [12-24] } \\
\hline Company & Program & Enrollment & Products Covered by Program \\
\hline \multirow{4}{*}{ Eli Lilly® } & $\begin{array}{c}\text { Lilly Care Foundation Patient Assistance } \\
\text { Program }\end{array}$ & $\begin{array}{l}\text { www.lillycare.com } \\
\text { 1-800-545-6962 }\end{array}$ & $\begin{array}{c}\text { Basaglar } \AA \text {, Glucagon } ₫, \text { Humalog } ®, \\
\text { Humulin } \AA \text {, Trulicity }{ }^{\circledR}\end{array}$ \\
\hline & $\begin{array}{l}\text { Humalog® U-200 Kwikpen Prescription } \\
\text { Co-Pay card }\end{array}$ & https://www.humalog.com/u-200-kwikpen/ & Humalog® U-200 KwikPen \\
\hline & Basaglar $®$ Prescription Co-pay Card & https://www.basaglar.com/en/savings-support & Basaglar® \\
\hline & Trulicity Savings Card & $\begin{array}{l}\text { https://www.trulicity.com/diabetes-treatment- } \\
\text { savings-card-and-support/ }\end{array}$ & Trulicity® \\
\hline \multirow[t]{4}{*}{ NovoNordisk $₫$} & $\begin{array}{l}\text { NovoNordisk Patient Assistance } \\
\text { Program (PAP)^ }\end{array}$ & $\begin{array}{l}\text { https://www.novocare.com/hcp/more-resources/ } \\
\text { PAP.html } \\
\text { 1-866-310-7549 }\end{array}$ & 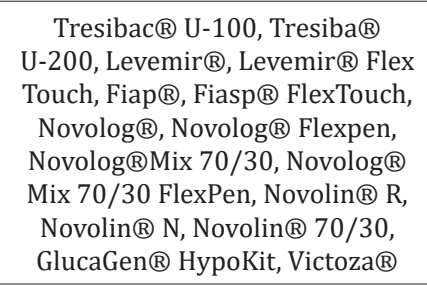 \\
\hline & Levmir® Instant Savings Card & $\begin{array}{l}\text { https://www.levemirpro.com/resources/patient- } \\
\text { support/instant-savings.html }\end{array}$ & Levemir ${ }^{\circledR}$ \\
\hline & Novo Nordisk prescription savings card & $\begin{array}{l}\text { https://www.rapidactinginsulin.com/novolog/save- } \\
\text { on-novolog.html }\end{array}$ & Novolog $®$ \\
\hline & Victoza ${ }^{\circledR}$ Instant Savings Card & $\begin{array}{l}\text { https://www.novocare.com/victoza/savings-card. } \\
\text { html }\end{array}$ & Victoza ${ }^{\circledR}$ \\
\hline \multirow{5}{*}{ Sanofiß } & Sanofi Patient Connection Program & $\begin{array}{l}\text { http://www.sanofipatientconnection.com/patient- } \\
\text { assistance-connection } \\
\text { 1-888-847-4877 }\end{array}$ & $\begin{array}{l}\text { ADMELOG®, Apidra } \AA \text {, Lantus } \AA \text {, } \\
\text { SOLIQUA®, Toujeo } \AA\end{array}$ \\
\hline & Apidra® No Co-Pay Savings program & https://www.apidra.com/register/default.aspx & Apidra ${ }^{\circledR}$ \\
\hline & Lantus ${ }^{\circledR}$ co-pay card & $\begin{array}{l}\text { https://www.lantus.com/sign-up/savings-and- } \\
\text { support }\end{array}$ & Lantus ${ }^{\circledR}$ \\
\hline & Soliqua® ${ }^{\circledR}$ 100/33 co-pay card & $\begin{array}{l}\text { https://www.soliqua100-33.com/savings-and- } \\
\text { support }\end{array}$ & SOLIQUA® $100 / 33$ \\
\hline & Toujeo $®$ co-pay card & $\begin{array}{l}\text { https://www.toujeo.com/toujeo-savings-card- } \\
\text { coupon-and-support }\end{array}$ & Toujeo® \\
\hline
\end{tabular}

Cite this article: Hyma P Gogineni, Revant V Gogineni. Increasing Insulin Prices - Role of Pharmacists in Assisting Patients with Diabetes to Enhance Access. Biomed Sci\&Tech Res 8(2)- 2018. BJSTR MS.ID.001633. DOI: 10.26717/ BJSTR.2018.08.001633. g) Cost-sharing for insured patients with diabetes should be based on the lowest available price.

h) Uninsured people or Medicare Part D patients with coverage gap (donut hole) should have access to high-quality low-cost insulins.

Pharmacists are in a prime position to educate patients and other healthcare providers as per ADA recommendations about the costs, advantages and disadvantages of various insulin formulations as patients first stop to pick up the insulin is from pharmacy. They can assist patients with diabetes to select the most appropriate diabetes management including insulin based on individual patient characteristics. There are numerous ways that pharmacists can help patients with diabetes to afford their medications by modifying their regimens for cheaper alternatives or by finding assistance programs. Pharmacists are perfectly positioned to navigate patients and other healthcare providers to various resources to enhance accessibility and affordability to combat the insulin price inflation. Here are few of many resources that are available from pharmaceutical companies and web-based programs listed in Table 1 and Table 2 can be useful to guide both insured and uninsured patients. Note that the list may not be all-inclusive. 
Table 2: Users of these resources are cautioned to use their own professional judgement and consult other resources prior to making clinical judgment based on the content of this document. Information and the internet links in this article are current as of the date of publication

\begin{tabular}{|c|c|c|}
\hline \multicolumn{3}{|c|}{ Patient Assistance Programs and Prescription Saving Programs [25-36] } \\
\hline Program & Website & Brief Description \\
\hline $\begin{array}{l}\text { Partnership for prescription } \\
\text { assistance }\end{array}$ & https://www.pparx.org/ & $\begin{array}{l}\text { Assists both uninsured and underinsured patients with affordable access to } \\
\text { prescription programs from private and public assistance programs. It also } \\
\text { helps patients to find free healthcare clinics across the country. It is a free } \\
\text { service }\end{array}$ \\
\hline Rx Assist & http://www.rxassist.org/ & $\begin{array}{l}\text { Provides comprehensive database of patient assistance programs for both } \\
\text { healthcare providers and patients. }\end{array}$ \\
\hline Rx Hope & https://www.rxhope.com/ & $\begin{array}{l}\text { Advocates and facilitates the patient assistance program process easier and } \\
\text { this site can be used by both healthcare providers and patients. }\end{array}$ \\
\hline BenefitsCheckUp & https://www.benefitscheckup.org/ & $\begin{array}{l}\text { Provides help to reduced prescription drug costs, also includes application for } \\
\text { Extra Help (Medicare Low Income Subsidy). This site is run by the National } \\
\text { Council on Aging (NCOA). This program helps people over age of } 55 .\end{array}$ \\
\hline Needy Meds & https://www.needymeds.org/ & $\begin{array}{l}\text { Provides prescription assistance by drug name, medical diagnosis, free low- } \\
\text { cost sliding scale clinics, medical transportation, scholarships and government } \\
\text { programs. It also includes drug discount card and } \$ 4 \text { generic drug discount } \\
\text { programs. }\end{array}$ \\
\hline Good Rx & https://www.goodrx.com/ & $\begin{array}{l}\text { Compares prices between pharmacies for a specific drug. Has a free app for } \\
\text { both iOS and Android with the coupons built into the app and also offers } \\
\text { discount card. }\end{array}$ \\
\hline Destination $\mathrm{Rx}$ & $\begin{array}{l}\text { https://drugcompare.destinationrx. } \\
\text { com/Home.aspx }\end{array}$ & $\begin{array}{l}\text { Compares prices and averages from multiple pharmacies, not specific to one } \\
\text { pharmacy. }\end{array}$ \\
\hline Inside $\mathrm{Rx}$ & https://www.insiderx.com/ & $\begin{array}{l}\text { Compares prices and averages from multiple pharmacies, not specific to one } \\
\text { pharmacy. It also offers savings card. }\end{array}$ \\
\hline Reduced RxTM & https://www.reducedrx.com/ & Prescription savings program for both insured and uninsured patients. \\
\hline Blink Health & https://www.blinkhealth.com/ & $\begin{array}{l}\text { Prescription savings program for both insured and uninsured patients, } \\
\text { patients have to pay online and pickup insulin from any pharmacy. }\end{array}$ \\
\hline CR3Diabetes & https://www.cr3diabetes.org/ & $\begin{array}{l}\text { Provides medical devices and supplies for those unable to afford the cost } \\
\text { which includes insulin pumps and supplies with discounted rates. }\end{array}$ \\
\hline Insulin for Life USA & http://ifl-usa.org/ & $\begin{array}{l}\text { Rescues unused diabetes supplies in the US and delivers them across the world } \\
\text { who have no access to these supplies. }\end{array}$ \\
\hline
\end{tabular}

There are many strategies that healthcare providers can implement to reduce costs for patients with diabetes. The Yale investigators wanted to see how the insulin price jump affected patients with diabetes in the real world, in the summer of 2017. 199 patients completed a seven-page questionnaire during a visit to the diabetes center. The patients were prescribed insulin within 6 months, and had their hemoglobin A1C checked during their visit, or within 3 months. Patients were primarily Caucasians, followed by black, then Hispanics, equally split between the genders, slightly more type 2 diabetes than type 1 . There were six questions key to cost of insulin therapy: In the past 12 months did you, because of cost, use less insulin than prescribed; try to stretch out your insulin; take smaller doses of insulin than prescribed; stop insulin; not fill an insulin prescription or didn't start insulin? Fifty-one patients answered "yes" to at least one of those questions signaling that they were using less insulin than prescribed because they couldn't afford insulin.

Compared with other patients, they were three times more likely to have higher HbA1C levels over 9\% controlling for age, gender, duration of diabetes, and income $(\mathrm{P}=0.03)$. The problem was greatest among people making less than $\$ 100,000$ per year and was not associated with race or the type of diabetes. Employer health coverage was not protective, and patients who were covered by a mix of government and employer insurance were at a greater risk of underuse.10 This study clearly demonstrated out-of-patient costs and the income level negatively impacts the overall health of patients with diabetes. According to National Diabetes Statistical report in 2014 [12-24], there were about 207,000 emergency department visits for hyperglycemic crisis [11]. Removing one barrier which is cost of insulin can set patients up for successful implementation of the individualized care plan diligently designed by healthcare providers. Furthermore, as ADA recommended incorporating patient education and continuing supply of insulin and diabetic supplies will enhance patient outcomes with optimal blood glucose control and decreases overall costs, further studies needed to evaluate this. Overall, helping patients with insulin costs has the potential to generate considerable financial and clinical rewards for patients, healthcare providers and society [25-36].

\section{Conclusion}

Fredrick Banting, John Macleod, Charles Best sold their insulin patent to University of Toronto for a total of three dollars as they envisioned no one should get profit from a lifesaving drug. Current insulin prices have been tripled, patients with diabetes are having hard time to afford the insulin and assessing insulin as this may 
be life and death for some patients. Now-a-days pharmacies are located every corner and patients with diabetes can have easier access to pharmacists than other healthcare providers, which gives an opportunity to guide patients with diabetes to appropriate resources which includes: patient assistance programs, prescription savings programs, pharmaceutical assistance programs or copay cards. The short-term solution for the escalating price of insulin may be educating patients on the cost-effectiveness regimens, selecting less expensive human insulin over insulin analogs, choosing a less expensive delivery method such as an insulin vial versus insulin pre-filled syringes and directing them to no cost to low-cost prescription savings programs. The long-term solution relies on multiple approaches including increase transparency, promoting legislative change in regard to negotiating prices, pushing incentives for generic forms.

\section{References}

1. Rosenfeld L (2002) Insulin: discovery and controversy. Clin Chem 48: 2270-2288.

2. Quianzon CC, Cheikh I (2012) History of insulin. Journal of Community Hospital Internal Medicine Perspectives 2(2).

3. Bullard KM, Cowie CC, Lessem SE, (2018) Prevalence of Diagnosed Diabetes in Adults by Diabetes Type United States, 2016. Morbidity and Mortality Weekly Report 67(12): 359-361.

4. (2015) United States Diabetes Surveillance System. Diabetic medication use [Internet] (2015) Atlanta, GA, Centers for Disease Control and Prevention.

5. Yang W, Dall TM, Beronjia K, Semilla AP, Chakrabarti R, et al. (2018) Economic costs of diabetes in the US in 2017. American Diabetes Association.

6. Schneider A (2016) Insulin price spike leaves diabetes patients in crisis [article online]. Montana Standard,

7. Hua X, Carvalho N, Tew M, Huang ES, Herman WH, Clarke P (2016) Expenditures and prices of antihyperglycemic medications in the United States: 2002-2013. JAMA 315: 1400-1402.

8. Picchi A (2016) Soaring insulin prices have diabetics feeling the pain [article online]. CBS News Money Watch.

9. Cefalu WT, Dawes DE, Gavlak G, Dawes, Gina Gavlak, Dana Goldman (2018) Insulin Access and Affordability Working Group: conclusions and recommendations. Insulin Access and Affordability Working Group - Diabetes Care.

10. Herkert DM, Vijayakumar P, Luo J, Schwartz J, Rabin TL, et al. (2018) Cost-Related Insulin Underuse is Common and Associated with Poor Glycemic Control. ADA

11. (2017) National Diabetes Statistics Report 2017.

12. (2018) Lilly Care Foundation Patient Assistance Program.

13. (2018) Humalog® U-200 Kwikpen Prescription Co-Pay card.

14. (2018) Basaglar® Prescription Co-pay Card.

15. (2018) Trulicity Savings Card.

16. (2018) NovoNordisk Patient Assistance Program (PAP).

17. (2018) Levmir® Instant Savings Card.

18. (2018) Novo Nordisk prescription savings card.

19. (2018) Victoza® Instant Savings Card.

20. (2018) Sanofi Patient Connection Program.

21. (2018) Apidra $®$ No Co-Pay Savings program.

22. (2018) Lantus $®$ co-pay card.

23. (2018) Soliqua® 100/33 co-pay card.

24. (2018) Toujeo® co-pay card.

25. (2018) Partnership for prescription assistance.

26. (2018) Rx Assist.

27. (2018) Rx Hope.

28. (2018) Benefits CheckUp.

29. (2018) NeedyMeds.

30. (2018) Good Rx.

31. (2018) Destination Rx.

32. (2018) InsideRx.

33. (2018) Reduced RxTM.

34. (2018) Blink Health.

35. (2018) CR3Diabetes.

36. (2018) Insulin for Life, USA.
ISSN: 2574-1241

DOI: 10.26717/BJSTR.2018.08.001633

Hyma P Gogineni. Biomed J Sci \& Tech Res

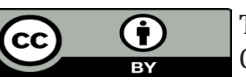

This work is licensed under Creative Commons Attribution 4.0 License

Submission Link: https://biomedres.us/submit-manuscript.php

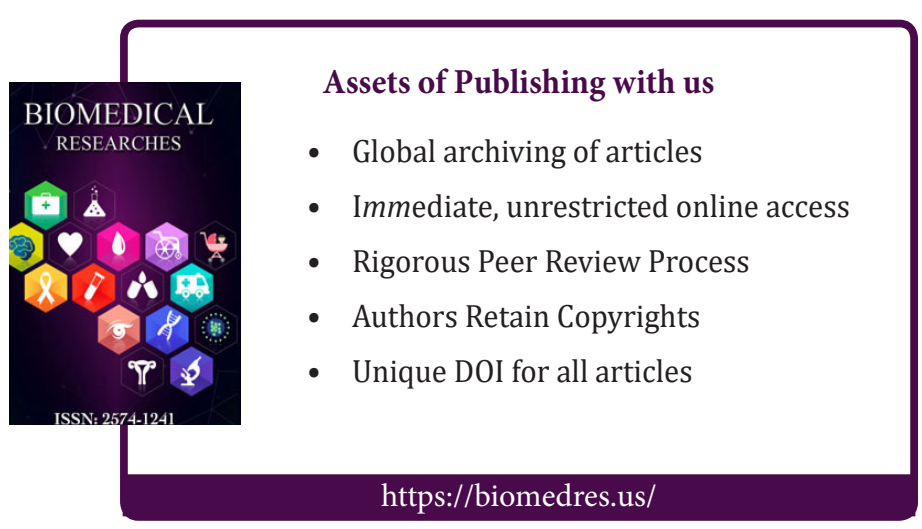

